\title{
PENERIMAAN DAN PENOLAKAN HUKUM YANG DIBENTUK PEMERINTAH INDONESIA
}

\author{
Ditulis oleh: \\ Nomansar, Fire Carlis
}

\begin{abstract}
Keamanan dan ketertiban dapat berjalan sebagaimana mestinya ketika ada norma dalam hal ini norma hukum. Hukum ini sangat berpengaruh terhadap kepastian kehidupan suatu Negara. Adanya hukum, maka adanya kenyamanan. Namun hukum ini tidak selamanya dapat diterima dengan baik oleh setiap orang, karena adakalanya hukum yang ada bias menjadi ancaman bagi orang tertentu maupun orang banyak. Kondisi ini menarik untuk dicermati lebih jauh lagi supaya ada gambaran atau fakta atas suatu abstraksi hukum. Tulisan ini ditelusuri berdasarkan metode penelitian hukum sosiologi yang mana didasarkan juga pada metode penelitian doktrinal. Data yang dibutuhkan dalam penelitian ini yakni ada tiga jenis. Ketiga jenis data tersebut meliputi interview atau wawancara, pengamatan atau observasi, dan studi dokumen. Ketiga data tersebut telah berhasil dikumpulkan yang kesimpulannya menyatakan bahwa ada penerimaan terhadap hukum yang dibentuk di Indonesia dan ada juga yang menolaknya. Hal ini terjadi karena faktor ketidakpercayaan terhadap pihak yang membentuk regulasi tersebut, karena isi dari aturan tersebut tidak mencerminkan asas-asas pembentukan hukum yang baik, serta karena masyakaratnya memang yang tidak tertib alias tidak taat terhadap pemerintahan yang sedang menjabat. Ketidaktataan masyarakat ini disebabkan karena tidak cocoknya mereka kepada pemerintah yang sedang menjabat karena masyarakat tersebut memiliki pilihan polik yang berbeda pada saat pemilihan Presiden dan Wakil Presiden pada saat pemilihan. Hukum yang baik mestinya tidak didasarkan pada keegoisan dari pihak yang membuat tapi didasarkan pada apa kepentingan pengaturan tersebut dengan disesuaikan pada jenjang suatu peraturan Perundang-undangan yang berlaku di Indonesia. Selain itu, aturan yang dibuat mestinya responsive terhadap keadaan masyarakat Indonesia dengan mengedepankan pada aspek menerima masukan dan melakukan observasi serta penelitian di tengah-tengah masyarakat. Kalau hal itu sudah dilakukan, maka mustahil akan ada pihak yang melakukan protes terhadap keadaan seperti itu. Kalaupun ada yang protes, maka bentuk protes tersebut dipahami dan dilakukan evaluasi. Kalau masuk akal, maka ada dua pilihan yang dilakukan yaitu mengganti suatu peraturan atau mengubah suatu peraturan. Kalau protes itu tanpa dasar alias mengada-ngada, maka itu dianggap sebagai pihan yang sedang mencari masalah dan menghambat pembangunan hukum di masyarakat Indonesia.
\end{abstract}

Kata Kunci: Hukum; Dibentuk; Indonesia.

\section{REFERENSI}


Nurmardiansyah, Eko. "Eco-Philosophy dan Implikasinya dalam Politik Hukum Lingkungan di Indonesia." Melintas 30.1 (2014): 70-104.

Saraswati, R. (2014). Arah Politik Hukum Pengaturan Desa ke Depan (Ius Constituendum). Masalah-Masalah Hukum, 43(3), 313-321.

Telaumbanua, Dalinama. 2018. "Pembentukan Peraturan Daerah Kabupaten/Kota.” Jurnal Education and Development. vol. 4, no. 1

MD, Mahfud, Politik Hukum Di Indonesia, RajaGrafindo Persada, Jakarta, 2009.

Telaumbanua, Dalinama. 2019. "Kumpulan Undang-undang KPK Dalam Satu Naskah.” LawArXiv. November 29. doi:10.31228/osf.io/ysju2.

http://www.lombalomba.com/?s=penegakan+hukum+orde+lama

Telaumbanua, Dalinama. 2020. "Restriktif Status Dewan Pengawas KPK." Jurnal Education and Development. vol. 8, no. 1

https://osf.io/xtdba/download?format=pdf http://id.wikipedia.org/wiki/Orde_Baru

Telaumbanua, Dalinama. 2019. Hukum Ketenagakerjaan. Deepublish.

Telaumbanua, Dalinama. 2019. "Analisis Peraturan Perundang-undangan Koperasi Dengan Tujuan Hukum."

https:/www.kompasiana.com/ismawati26/5cd2480275065753492fc712/politik-dalamhukum-di-indonesia

https://www.researchgate.net/publication/337241250_Politik_Hukum_di_Indonesia http://ditjenpp.kemenkumham.go.id/htn-dan-puu/480-politik-perundang-undangan.html 